\title{
Anthropogenic carbon distribution in the Ross Sea, Antarctica
}

\author{
S. SANDRINI I ${ }^{1 *}$, N. AIT-AMEUR ${ }^{2}$, P. RIVARO ${ }^{3}$, S. MASSOLO ${ }^{3}$, F. TOURATIER ${ }^{2}$, L. TOSITTI ${ }^{1}$ and C. GOYET ${ }^{2}$ \\ ${ }^{1}$ University of Bologna, Department of Chemistry “G. Ciamician”, via Selmi, 2, 40126 Bologna, Italy \\ ${ }^{2}$ LBDSI-University of Perpignan, 52 Avenue Paul Alduy, Perpignan, France \\ ${ }^{3}$ University of Genoa, Department of Chemistry and Industrial Chemistry, via Dodecaneso, 31, 16146 Genoa, Italy \\ *silvia.sandrini@unibo.it,silvia.sandrini@sacmi.it
}

\begin{abstract}
The Ross Sea is an area of dense water formation within the Southern Ocean, hence it potentially plays an important role for anthropogenic $\mathrm{CO}_{2}$ sequestration. In order to estimate the penetration of anthropogenic carbon in the Ross Sea from total inorganic carbon $\left(\mathrm{TCO}_{2}\right)$ measurements carried out in 2002-03 Antarctic Italian Expedition, we applied two independent models. Anthropogenic carbon was present throughout the water column. The highest concentrations were associated with the recently ventilated shelf waters, namely High Salinity Shelf Water (HSSW) and Ice Shelf Water (ISW), due to their recent contact with the atmosphere. The lowest concentrations were observed for Circumpolar Deep Water (CDW), due to its relatively older ventilation age. This water mass intrudes onto the shelf in some parts of the Ross Sea and hence is observed in the sampled section, where it is recognizable for its low $\mathrm{O}_{2}$ and high $\mathrm{TCO}_{2}$ concentrations. The overflow of the dense High Salinity Shelf Water out of the continental slope was observed in the area off Cape Adare. Since this recently formed shelf water contributes to the formation of the Antarctic Bottom Water (AABW), this process represents a pathway for anthropogenic carbon export down to the deep ocean.
\end{abstract}

Received 8 February 2006, accepted 17 January 2007

Key words: atmospheric $\mathrm{CO}_{2}$ sequestration, chemical tracers, mixing, $\mathrm{TCO}_{2}$, water mass

\section{Introduction}

Continuous combustion of fossil fuels and land-use change raised the atmospheric $\mathrm{CO}_{2}$ concentration from $280 \mathrm{ppm}$ in preindustrial era to $375 \mathrm{ppm}$ at present, with a rate of increase unprecedented compared to the past 20000 years (IPCC 2001). However, the increase of atmospheric $\mathrm{CO}_{2}$ is lower than expected. During the 1980s the discharge of $\mathrm{CO}_{2}$ due to the fossil fuel burning $\left(5.4 \pm 0.3 \mathrm{PgC} \mathrm{yr}^{-1}\right)$ was higher than the accumulation of anthropogenic $\mathrm{CO}_{2}$ in the atmosphere (only $3.3 \pm 0.1 \mathrm{PgC} \mathrm{yr}^{-1}$, Sarmiento \& Gruber 2002). According to these authors the difference, which amounts to $2.1 \pm 0.3 \mathrm{PgC} \mathrm{yr}^{-1}$, is taken up by the ocean $\left(1.9 \pm 0.6 \mathrm{PgC} \mathrm{yr}^{-1}\right)$ and by the biosphere $(0.2 \pm$

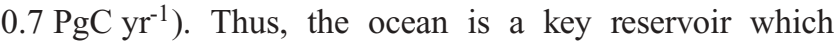
buffers the accumulation of anthropogenic $\mathrm{CO}_{2}$ in the atmosphere. This means that how much $\mathrm{CO}_{2}$ remains in the atmosphere is in turn controlled by the amount taken up by the oceans (Chen \& Drake 1986).

The ocean absorption of atmospheric $\mathrm{CO}_{2}$ is not evenly distributed over the world ocean and is strongly influenced by circulation: the deepest penetration is associated with convergence zones at temperate latitudes, while low vertical penetration is generally found in upwelling areas (Sabine et al. 2004).

Deep water formation is certainly one important pathway for the sequestration of atmospheric $\mathrm{CO}_{2}$ and its transport to the deep ocean. In particular Antarctic Bottom Water $(\mathrm{AABW})$ formed in the Southern Ocean may provide a mechanism to transport anthropogenic $\mathrm{CO}_{2}$ into the ocean. The continental shelves of Antarctica are one of the two main sources of deep waters for the global ocean, along with the Nordic seas in the North Atlantic Ocean (Doney \& Hecht 2001). AABW is formed at a limited number of locations along the Antarctic coast, where very dense and cold $\left(\theta<-1.7^{\circ} \mathrm{C}\right)$ near surface Shelf Waters are created by ocean-ice-atmosphere interaction. These waters then sink down along the continental slope as narrow and thin (tens of kilometres wide and 100-200 m thick) bottom boundary currents (Price \& Baringer 1994). The overflow of AABW is then counterweighed by the entrainment of warmer $\left(\theta>0^{\circ} \mathrm{C}\right)$ Circumpolar Deep Water (CDW) (Orsi et al. 1999).

Anthropogenic carbon concentration cannot be measured directly. It can only be estimated using measured properties of seawater. Back calculation techniques allow the separation of the anthropogenic $\mathrm{CO}_{2}$ from the bulk of $\mathrm{TCO}_{2}$ (total inorganic carbon) in the water column, taking into account $\mathrm{TCO}_{2}$ variations due to circulation, remineralization and dissolution of calcium carbonate. Several back calculation techniques followed the first attempts by Brewer (1978) and Chen \& Millero (1979) to separate the anthropogenic $\mathrm{CO}_{2}$ signal, trying to lower the uncertainties associated with these methods (Shiller 1981, Broecker et al. 1985). Other authors proposed different models, such as the Mix method of Goyet et al. (1999), based on an optimum multiparametric mixing analysis 
(Tomczak 1981, Mackas et al. 1987) and the most recent TrOCA method proposed by Touratier \& Goyet (2004a).

One of the key questions concerning the Southern Ocean's role in the anthropogenic carbon sequestration is whether this ocean, like the North Atlantic Ocean, is able to take up huge amounts of atmospheric $\mathrm{CO}_{2}$. Model based estimates have shown a large sink for anthropogenic carbon $\left(\mathrm{C}_{\mathrm{ant}}\right)$ in the Southern Ocean south of $40^{\circ} \mathrm{S}$ (Sarmiento et al. 1998, Matear \& Hirst 1999), while most data-based methods estimate very little storage of anthropogenic $\mathrm{CO}_{2}$ south of $50^{\circ} \mathrm{S}$ (Poisson \& Chen 1987, Gruber 1998, Sabine et al. 1999, Hoppema et al. 2001, Sabine et al. 2004), amounting to only $9 \%$ of the global inventory (Sabine et al. 2004). From this reconstruction, low anthropogenic $\mathrm{CO}_{2}$ concentrations are associated with Antarctic Bottom Waters, even though the exact estimate of the anthropogenic $\mathrm{CO}_{2}$ content of this water is hampered by the limited carbon data in regions where these bottom waters are formed. Moreover, anthropogenic $\mathrm{CO}_{2}$ uptake predicted for the Southern Ocean by models show a large variability (Matear \& Hirst 1999). A contradiction exists between the low data based estimates of $\mathrm{C}_{\mathrm{ant}}$ and the significant concentrations of CFCs observed both along the continental slope and in Antarctic deep and bottom waters (Meredith et al. 2001, Orsi et al. 2002, Rivaro et al. 2004a). These factors highlight the need for new direct estimates in the Southern Ocean. Today, in fact, there are only scarce $\mathrm{TCO}_{2}$ measurements throughout the water column in the Ross Sea (Bates et al. 1998, Gordon et al. 2000, Sweeney et al. 2000a, 2000b, Sweeney 2003) and in the Weddell Sea (Poisson \& Chen 1987, Hoppema et al. 1998, 2002), thus leading to very few studies of anthropogenic carbon distribution in these two areas of AABW formation (Poisson \& Chen 1987, Lo Monaco et al. 2005a, 2005b).

This study is based on data collected during the summer 2003 (January-February) within the framework of the XVIII Antarctic Expedition of the Italian PNRA (National Program of Research in Antarctica) activities. The aim is to observe the inorganic carbon properties of the different water masses which characterize the western Ross Sea during the summer and to estimate their anthropogenic carbon content. The summer water masses of the Ross Sea are extensively described in literature (Jacobs et al. 1970, 1985, 1989, Carmack 1977, Locarnini 1994, Jacobs \& Giulivi 1999, Budillon et al. 1999, 2003). They are represented by five main water types: High Salinity Shelf Water (HSSW), Ice Shelf Water (ISW), Circumpolar Deep Water (CDW), Modified Circumpolar Deep Water (MCDW), Antarctic Surface Water (AASW). Each of them can be identified by its total alkalinity (TA), total inorganic carbon $\left(\mathrm{TCO}_{2}\right)$, dissolved oxygen $\left(\mathrm{O}_{2}\right)$, nutrient and CFC concentrations, and different concentrations of anthropogenic carbon. For the estimation of anthropogenic carbon in the waters of the Ross Sea we applied two independent data-based methods with the aim of comparing the results obtained by the two approaches. Actually few comparisons exist between different methods (back-calculation techniques and/or models) to estimate anthropogenic carbon (Coatanoan et al. 2001, Sabine \& Feely 2001, Lo Monaco et al. 2005b, Friis 2006). This work presents the first estimate of anthropogenic carbon distribution in the Ross Sea using two independent methods which are compared with the anthropogenic CFC tracer. It further provides an estimate of the anthropogenic carbon uptake by the Ross Sea.

\section{Materials and methods}

\section{Sampling and analysis}

Within the framework of the XVIII expedition of the Italian National Program of Research in Antarctica, the CLIMA

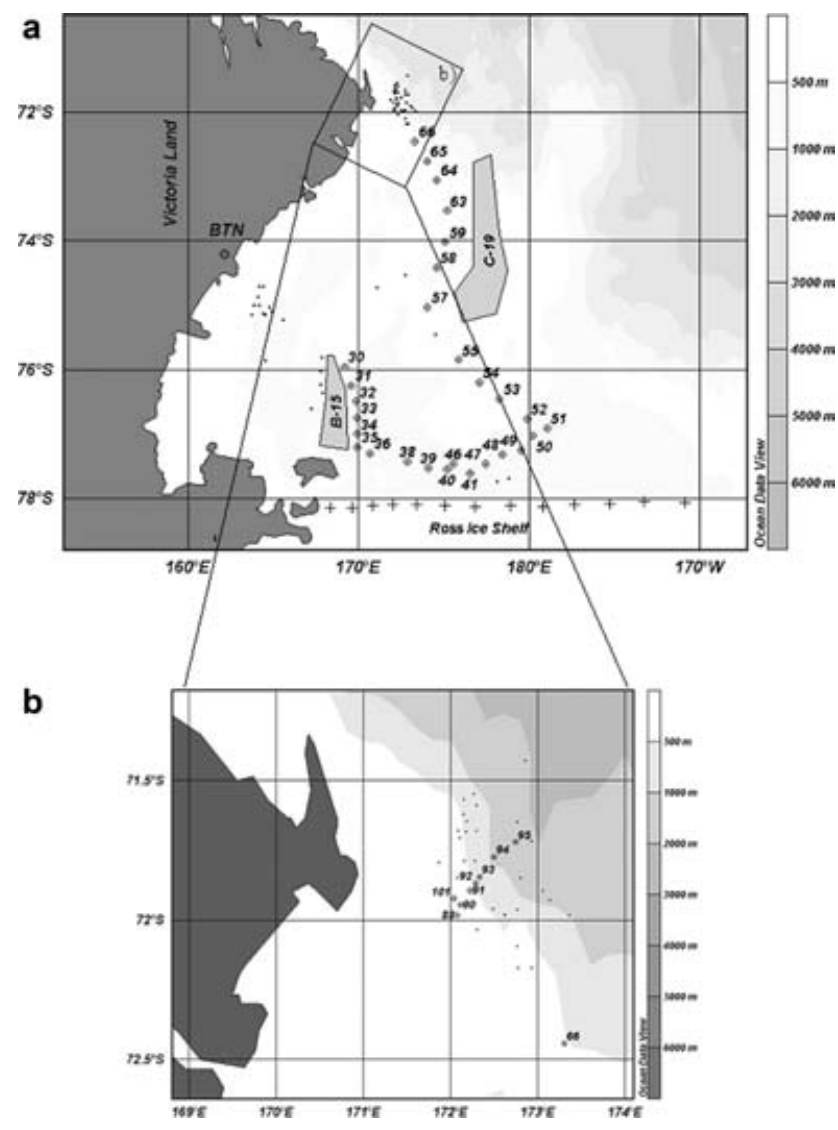

Fig. 1a. Map showing the location of stations in the general survey in the Ross Sea during the CLIMA cruise in January-February 2003. Only the stations where $\mathrm{TCO}_{2}$ and $\mathrm{TA}$ data were collected are shown. The zoom b. reports the stations of a mesoscale experiment performed across the shelf break in the area off Cape Adare. The stations labelled are the ones used for the section $\mathrm{A}-\mathrm{B}-\mathrm{C}$ studied in this paper. The crosses on the map indicate the extent of the Ross Ice Shelf. 
(Climatic Long-term Interactions for the Mass-balance in Antarctica) project cruise was conducted from 5 January-5 March 2003, in the Ross Sea on board the RV Italica. During this cruise 126 stations were sampled for the hydrology and water chemistry parameters. 570 discrete seawater samples were also collected for TA and $\mathrm{TCO}_{2}$ measurements at 86 of these stations (Fig. 1).

Seawater samples and hydrographical data (depth, temperature, and salinity) were collected using a multiparameter CTD probe (SBE 9/11) equipped with two temperature and two conductivity sensors and with a SBE Carousel water sampler.

Samples for TA and $\mathrm{TCO}_{2}$ analysis were collected into $500 \mathrm{ml}$ borosilicate glass screw cap bottles using standard sampling protocols (Dickson \& Goyet 1994) and poisoned with saturated $\mathrm{HgCl}_{2}$ solution to prevent modification in $\mathrm{TCO}_{2}$ due to biological activity. Most of the samples were analysed on board shortly after collection, while the remaining samples were stored in the dark at $+4{ }^{\circ} \mathrm{C}$ and analysed later at the Department of Chemistry of the University of Bologna.

TA and $\mathrm{TCO}_{2}$ were measured simultaneously by a potentiometric titration system using the method of Edmond (1970) described in the DOE Handbook of Methods for $\mathrm{CO}_{2}$ Analysis (Dickson \& Goyet 1994). TA and $\mathrm{TCO}_{2}$ were estimated using a non-linear least-squares approach similar to that used by Dickson (1981). The accuracy of the measurements $\left( \pm 4 \mu \mathrm{mol} \mathrm{kg}^{-1}\right.$ for TA and $\mathrm{TCO}_{2}$ ) was monitored by routine analysis of Certified Reference Materials (CRMs, batch 58, provided by A.G. Dickson, Scripps Institution of Oceanography). The precision, evaluated using replicate analysis of surface and deep samples, was estimated to be \pm 3 and $\pm 4 \mu \mathrm{mol} \mathrm{kg}^{-1}$ for TA and $\mathrm{TCO}_{2}$ respectively.

Dissolved oxygen was measured on board by Winkler method using automated micro-titrations (Grasshoff 1983). Measurement precision was $\pm 0.5 \mu \mathrm{mol} \mathrm{kg}{ }^{-1}$.

Water samples for tracer analyses were collected from $12 \mathrm{~L}$ Niskin bottles, equipped with an epoxy coated stainless steel spring, in $60 \mathrm{ml}$ glass ampoules avoiding any contact with air. All ampoules were flame sealed in Ultra Pure $\mathrm{N}_{2}$ atmosphere. The flame-sealed ampoules were stored in dark, cold conditions $\left(+4^{\circ} \mathrm{C}\right)$. The CFCs were analysed with a specific purge and trap gas chromatographic system with a ${ }^{63} \mathrm{Ni}$ electron capture as detector according to the methods described by Bullister \& Weiss (1988) and Smethie et al. (1988). A 5090 Hewlett Packard GC was used with a pre-column of Porasil $\mathrm{C}$ and an analytical column packed with Carbograph 1 (60-80 mesh) phase, $183 \mathrm{~cm}$ in length. Measurement precision was about $6 \%$.

\section{Anthropogenic $\mathrm{CO}_{2}$ estimate}

In order to estimate the anthropogenic $\mathrm{CO}_{2}$ in the Ross Sea we applied two independent methods. The first one, referred as MIX method, proposed by Goyet et al. (1999), is based on an Optimum Multiparametric Mixing Analysis. The second one, recently detailed in Touratier \& Goyet (2004a, 2004b), is based on the definition of the semi-conservative tracer TrOCA (Tracer combining Oxygen, inorganic Carbon and total Alkalinity).

These methods present the advantage of being independent and based upon very different assumptions. In addition they do not rely upon assumed preformed TA and $\mathrm{TCO}_{2}$ values, as most other methods do (Brewer 1978, Chen \& Millero 1979, Gruber 1998, Pérez et al. 2002, Lo Monaco et al. 2005a, 2005b).

\section{The MIX method}

This method is based on an Optimum Multiparametric Mixing Analysis (OMPA) (Tomczak 1981, Mackas et al. 1987) to quantify the contributions of the different water sources to the observed data. The detailed description of the analysis is provided in several works (Mackas et al. 1987, Tomczak \& Large 1989, You \& Tomczak 1993), and this kind of analysis has previously been used in the Ross Sea providing a good estimate of the mixing process and of the circulation of the different water masses (Budillon et al. 2003).

The mixing coefficient $\left(k_{j}\right)$ of the $(n)$ water sources are solved from the following system of equations:

$$
\begin{gathered}
\sum_{j=1}^{n} k_{j}=1 \quad \text { with } k_{j} \geq 0 \\
C_{m}=\sum_{j=1}^{n} k_{j} C_{j} \\
N C_{m}=\sum_{j=1}^{n} k_{j} N C_{j}+\Delta N C
\end{gathered}
$$

where the conservative tracers $\left(C_{m}\right)$ used are salinity and potential temperature and the non conservative tracers $\left(N C_{m}\right)$ are oxygen and total alkalinity.

The method used to estimate the concentration of anthropogenic $\mathrm{CO}_{2}$ in each water source is described in detail by Goyet et al. (1999). This method is based upon the assumption that, below the mixed layer depth, the measured $\mathrm{TCO}_{2}\left\lfloor\mathrm{TCO}_{2}^{\text {meas }}\right\rfloor$ results from three contributions:

$$
\left\lfloor\mathrm{TCO}_{2}^{\text {meas }}\right\rfloor=\left\lfloor\mathrm{TCO}_{2}^{\text {bio }}\right\rfloor+\left\lfloor\mathrm{TCO}_{2}^{\text {cir }}\right\rfloor+\left\lfloor\mathrm{TCO}_{2}^{\text {ant }}\right\rfloor
$$

Where $\left[\mathrm{TCO}_{2}^{\text {cir }}\right\rfloor$ is the concentration resulting from mixing and circulation of the different water masses; $\left\lfloor\mathrm{TCO}_{2}^{\text {bio }}\right\rfloor$ is the concentration affected by the biological processes and $\left\lfloor\mathrm{TCO}_{2}^{\text {ant }}\right\rfloor$ is the concentration of anthropogenic $\mathrm{CO}_{2}$. $\left\lfloor\mathrm{TCO}_{2}^{\text {cir }}\right\rfloor$ is calculated from the mixing coefficient $\left(k_{j}\right)$ and the preanthropogenic concentration $\left[\mathrm{TCO}_{2}^{\circ}\right\rfloor_{j}$ in each of the 
Table I. Physical and chemical properties for the water source used in the multiparameter analysis defined from the $\theta / \mathrm{S}$ diagram. Where, $\left[\mathrm{TCO} \mathrm{W}_{\mathrm{W}}\right] \mathrm{represents}$ the $\mathrm{TCO}_{2}$ measured in each water source " $j$ ". $\mathrm{a}, \mathrm{b}, \mathrm{c}, \mathrm{d}$, e represent the coefficients of the sigmoid function $\mathrm{F}_{j}(\mathrm{Z})$. with: $\mathrm{F}_{j}(\mathrm{Z})=\mathrm{a}-\mathrm{b} /\left[1-\mathrm{e}^{-(\mathrm{c}(\mathrm{z}-\mathrm{d}))}\right]^{\mathrm{e}}+\mathrm{b}$.

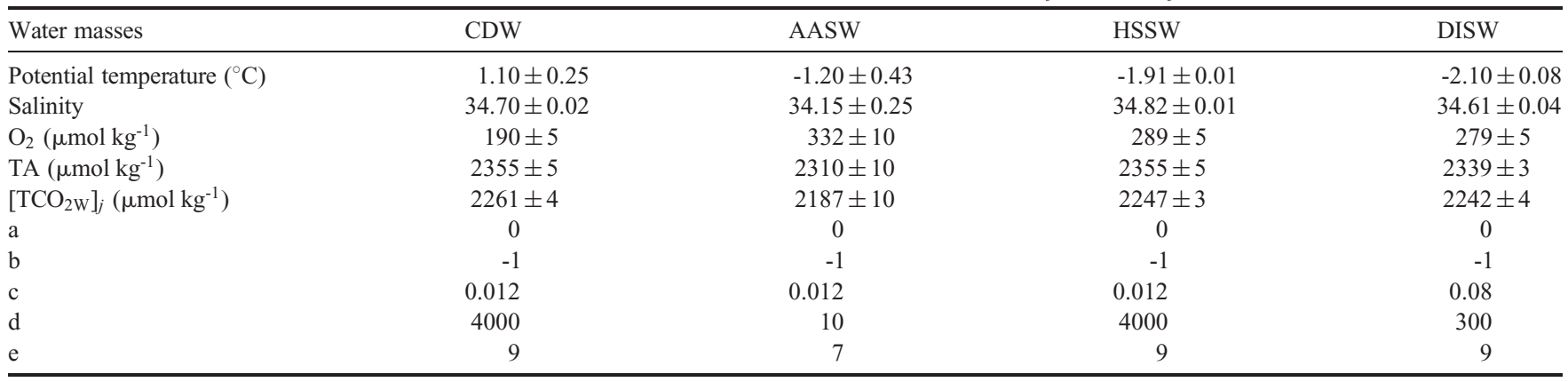

$n$ water source $j$

$$
\left\lfloor\mathrm{TCO}_{2}^{\mathrm{cir}}\right\rfloor=\sum_{j=1}^{n} k_{j}\left\lfloor\mathrm{TCO}_{2}^{\circ}\right\rfloor_{j}
$$

The term $\left\lfloor\mathrm{TCO}_{2}^{\text {bio }}\right\rfloor$ is computed as follow:

$$
\left\lfloor\mathrm{TCO}_{2}^{\text {bio }}\right\rfloor=0.78 \cdot \Delta \mathrm{O}_{2}+0.5 \cdot \Delta \mathrm{TA}
$$

Where $\Delta \mathrm{O}_{2}$ and $\Delta \mathrm{TA}$ are evaluated from the OMPA analysis (Eq. 3).

In Eq. (5), the preindustrial concentrations of the source waters $\left\lfloor\mathrm{TCO}_{2}^{\circ}\right\rfloor_{j}$ are unknown. Only the sum $\left\lfloor\mathrm{TCO}_{2}^{\text {ant }}+\right.$ $\left.\mathrm{TCO}_{2}^{\circ}\right\rfloor_{j}$ is known. Therefore, Eq. (5) is not explicitly used.

For the calculation of each $\left\lfloor\mathrm{TCO}_{2}^{\text {ant }}\right\rfloor$ a sigmoid function $\left(F_{j}(z)\right)$ is introduced to take into account the fact that anthropogenic $\mathrm{CO}_{2}$ decreases with increasing depth as the

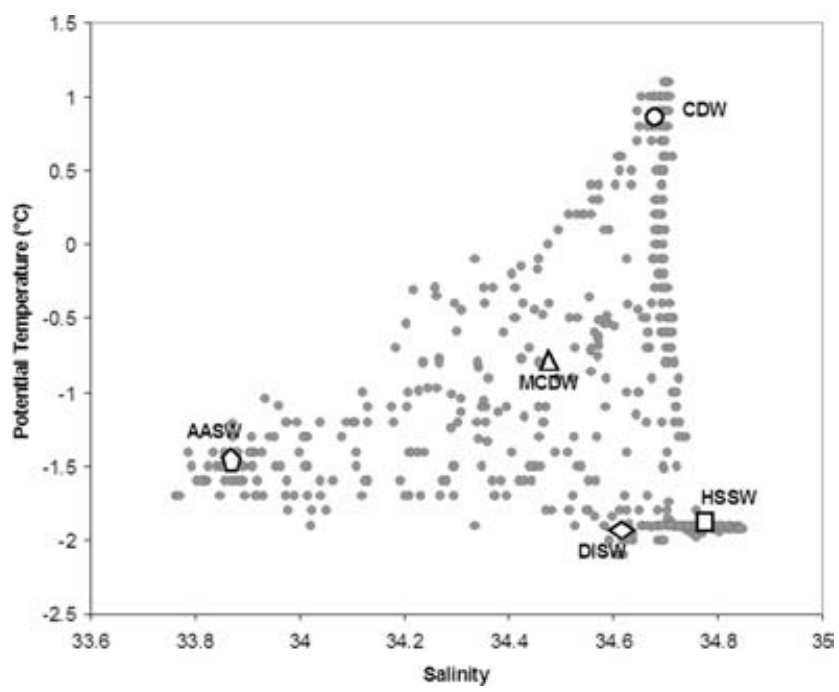

Fig. 2. Potential temperature versus salinity plot for all the stations sampled for $\mathrm{TCO}_{2}$ and TA. The black marks indicate the different source water type: they are Circumpolar Deep Water (CDW), Modified Circumpolar Deep Water (MCDW), High Salinity Shelf Water (HSSW), Deep Ice Shelf Water (DISW) and Antarctic Surface Waters (AASW). All of them except MCDW have been used in the Optimum Multiparametric Analysis. age of each water source differs. Various sigmoid functions are used according to the geographical location and depth of the water source. Therefore, the $\left[\mathrm{TCO}_{2}^{\mathrm{ant}}\right\rfloor$ of each water source is determined below the wintertime mixed layer from the following equation:

$$
\begin{aligned}
& {\left[\mathrm{TCO}_{2}^{\text {meas }}\right]-\left[\mathrm{TCO}_{2}^{\mathrm{bio}}\right]=\sum_{j=1}^{n} k_{j}\left(\left[\mathrm{TCO}_{2}^{\circ}\right]_{j}\right.} \\
& \left.+\left[\mathrm{TCO}_{2}^{\mathrm{ant}}\right]_{j} F_{j}(Z)\right)
\end{aligned}
$$

with the constraint:

$$
\left[\mathrm{TCO}_{2}^{\circ}\right]_{j}+\left\lfloor\mathrm{TCO}_{2}^{\mathrm{ant}}\right\rfloor_{j}=\left\lfloor\mathrm{TCO}_{2}^{\mathrm{w}}\right\rfloor_{j}
$$

The constants of the sigmoid and the values of $\left\lfloor\mathrm{TCO}_{2}^{\text {ant }}\right\rfloor_{j}$ are estimated iteratively by minimizing the residuals of Eq. (7) randomly around zero. Finally $\left\lfloor\mathrm{TCO}_{2}^{\text {ant }}\right\rfloor$ is calculated throughout the water column from the following equation:

$$
\mathrm{TCO}_{2}^{\mathrm{ant}}=\sum_{j=1}^{\mathrm{n}} k_{j}\left[\mathrm{TCO}_{2}^{\mathrm{ant}}\right]_{j} F_{j}(Z)
$$

The water source characteristics (potential temperature, salinity, $\mathrm{O}_{2}$, TA and $\mathrm{TCO}_{2}^{\mathrm{W}}$ ) used here are summarized in Table I. The different sources of water masses in the studied area were typically identified using the two conservative tracers temperature and salinity by analysing the $\theta / \mathrm{S}$ diagram for the hydrological stations sampled reported in Fig. 2. This figure indicates that five main different water sources were present: the Antarctic Surface Waters (AASW), the Circumpolar Deep Water (CDW), the Modified Circumpolar Deep Water (MCDW), the High Salinity Shelf Water (HSSW) and the Deep Ice Shelf Water (DISW). With the exception of MCDW, which is a modification of the water type CDW, all the other four water sources were considered in the analysis. The MCDW was not included into the multiparametric analysis because it did not change the results in terms of accuracy in the estimation of the mixing coefficients. Therefore, for the sake of simplicity, we used only four water masses. These water mass characteristics are similar to those described earlier by other authors (Jacobs et al. 1970, Budillon et al. 
2003, Sweeney 2003). The definition of the different water sources in terms of depth, salinity and temperature was hence based on the analysis of the $\theta / \mathrm{S}$ diagram in Fig. 2 . The most significant difference from literature definitions of water masses was for AASW, since the presence of intense phenomena of melting during the cruise made surface waters colder and less saline than that reported by other authors (Jacobs et al. 1985). For the non conservative tracers $\mathrm{O}_{2}$ and $\mathrm{TA}$, the values used in the multiparametric analysis were those measured during the cruise.

The mixed layer depth used for the analysis was $70 \mathrm{~m}$. It corresponds to the maximum mixed layer depth calculated from the density gradient of $0.02 \sigma_{\theta}$ as proposed by Price et al. (1978) and applied by Park et al. (1998) to Antarctic data.

\section{The TrOCA method}

This approach is based on the 'quasi-conservative' behaviour of the tracer TrOCA (see Eq. 10) in the same way as Broecker (1974) did for the quasi-conservative tracers NO and PO. It has been shown that TrOCA deviates significantly from the conservative behaviour when waters are thought to be contaminated with anthropogenic $\mathrm{CO}_{2}$ (Touratier \& Goyet 2004a). The analogous tracer, with conservative properties, $\operatorname{TrOCA}^{0}$ is hence defined in the same way (Eq. 11), but it is free of any anthropogenic contribution, i.e. $\operatorname{TrOCA}^{0}$ is defined as the pre-industrial TrOCA. In the original paper (Touratier \& Goyet 2004b), TrOCA ${ }^{0}$ was computed only as a function of $\theta$. Here we used an improved equation based on $\theta$ and TA (Eq. 12) (Touratier et al. 2007).

$$
\begin{gathered}
\operatorname{TrOCA}=\mathrm{O}_{2}+a\left(\mathrm{TCO}_{2}-\frac{1}{2} \mathrm{TA}\right) \\
\operatorname{TrOCA}^{0}=\mathrm{O}_{2}^{0}+a\left(\mathrm{TCO}_{2}^{0}-\frac{1}{2} \mathrm{TA}^{0}\right) \\
\operatorname{TrOCA}^{0}=e^{\left[b+c \theta+d / \mathrm{TA}^{2}\right]}
\end{gathered}
$$

Since in Eq. (10) only $\mathrm{TCO}_{2}$ is significantly affected by the atmospheric increase of $\mathrm{CO}_{2}, \mathrm{C}_{\mathrm{ant}}$ concentration can be simply computed as follows:

$$
\mathrm{C}_{\mathrm{ant}}=\mathrm{TCO}_{2}-\mathrm{TCO}_{2}^{0}=\frac{\operatorname{TrOCA}-\operatorname{TrOCA}^{0}}{a}
$$

where $a$ represents the Redfield coefficient. Since $\operatorname{TrOCA}^{\circ}$ has conservative property, the four parameters $(a, b, c, d)$ are determined by minimizing the fit standard error of Eq. (12). Hence the anthropogenic carbon is estimated using the following equation:

$$
\mathrm{C}_{\mathrm{ant}}=\frac{\begin{array}{c}
\mathrm{O}_{2}+1.279\left[\mathrm{TCO}_{2}-1 / 2 \mathrm{TA}\right] \\
-e^{\left[7.511-\left(1.087 \times 10^{-2}\right) \theta-7.81 \times 10^{5} / T A^{2}\right]}
\end{array}}{1.279}
$$

The uncertainty associated with the TrOCA method is estimated by error propagation using the uncertainty on the measured parameters and the coefficients. For this work, the uncertainty on $\mathrm{C}_{\text {ant }}$ is estimated to $4 \mu \mathrm{mol} \mathrm{\textrm {kg } ^ { - 1 }}$.

The original TrOCA method (Touratier \& Goyet 2004b) has previously been applied to the waters of the North Atlantic Ocean (Touratier \& Goyet 2004a), to the Equatorial Atlantic Ocean (Touratier et al. 2005), to the Mediterranean Sea (Aït-Ameur \& Goyet 2006) and to the Southern Ocean along $30^{\circ} \mathrm{E}$ between South Africa and Antarctica (WOCE line I6) (Lo Monaco et al. 2005a, 2005b). The improved $\operatorname{TrOCA}^{\circ}$ relationship was applied to the Indian Ocean (Touratier et al. 2007).

\section{Results and discussion}

\section{Ross Sea hydrology}

The Ross Sea can be defined as the area located in the Pacific sector of the Southern Ocean, bounded to the south by the Ross Ice Shelf and to the north-east by the $1000 \mathrm{~m}$ isobath (located at about $\left.73^{\circ} \mathrm{S}\right)$ between Cape Adare $\left(170^{\circ} \mathrm{E}\right)$ and Cape Colbeck $\left(158^{\circ} \mathrm{W}\right)$ (Fig. 1).

Different water masses can be identified on or near the continental shelf of the Ross Sea based on their thermohaline properties (Fig. 2).

Circumpolar Deep Water (CDW) originates in the Antarctic Circumpolar Current (ACC) at depths below $2000 \mathrm{~m}$, but reaches $200 \mathrm{~m}$ when it moves poleward (Locarnini 1994). It exhibits the highest temperature $\left(1.17^{\circ} \mathrm{C}\right)$ and is relatively salty (34.70). CDW episodically intrudes onto the shelf at specific locations related to bottom topography (Dinniman et al. 2003), providing heat to the shelf waters (Jacobs et al. 1985, Locarnini 1994, Jacobs \& Giulivi 1998, 1999, Gouretsky 1999, Budillon et al. 2000). Once on the shelf it mixes with fresher and colder shelf waters and is hence distinguished as Modified Circumpolar Deep Water (MCDW) (Jacobs et al. 1970), identifiable by a subsurface maximum temperature $\left(-0.84^{\circ} \mathrm{C}\right)$ and minimum dissolved oxygen (Jacobs et al. 1985, Budillon et al. 1999, Rivaro et al. 2003). Its salinity is lower than CDW being around 34.54.

The Ross Sea shelf is an area where dense waters form. The High Salinity Shelf Water (HSSW) is the densest one, with salinity ranging from 34.75 to 35.00 , increasing with depth and temperature close to the surface freezing point, between -1.95 and $-1.75^{\circ} \mathrm{C}$ (Budillon et al. 2002). HSSW is formed during the winter in the western side of the Ross Sea, in the Terra Nova Bay polynya area, by continual formation and removal of new ice by the strong katabatic winds flowing down to the Antarctic plateau (Kurtz \& Bromwich 1983, 1985, Jacobs et al. 1985, Van Woert 1999). This process increases seawater salinity by brine rejection during ice formation and, as a consequence, the water is denser and sinks. From there, one branch moves northward toward the shelf break in the area off Cape Adare, while another branch moves southward beneath the 

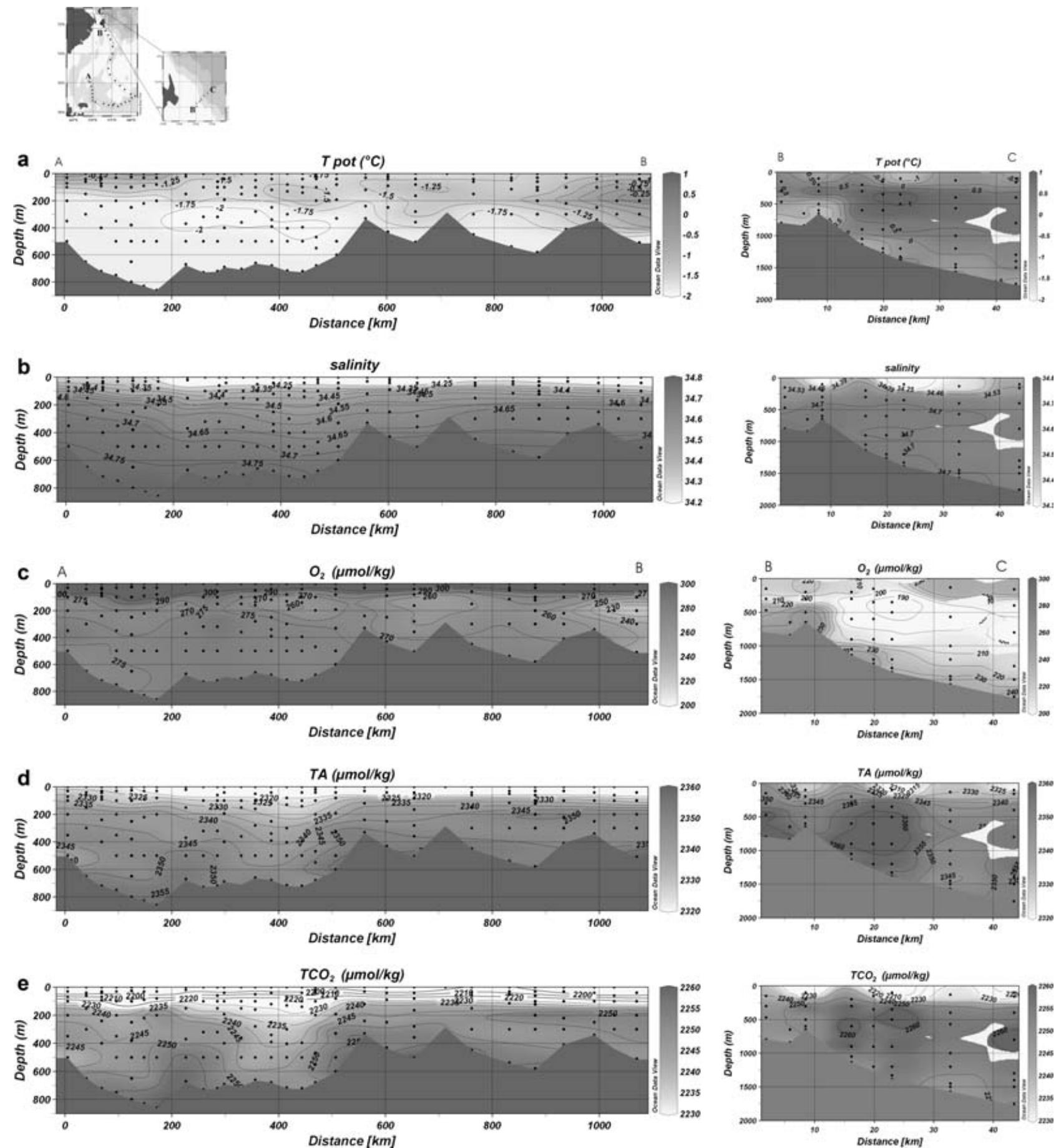

Fig. 3. Distribution of a. temperature $\left({ }^{\circ} \mathrm{C}\right)$, b. salinity, c. dissolved $\mathrm{O}_{2}\left(\mathrm{O}_{2}, \mu \mathrm{mol} \mathrm{kg}{ }^{-1}\right)$, d. total alkalinity $\left(\mathrm{TA}, \mu \mathrm{mol} \mathrm{kg}{ }^{-1}\right)$, and e. total inorganic carbon $\left(\mathrm{TCO}_{2}, \mu \mathrm{mol} \mathrm{kg}{ }^{-1}\right)$ along the $\mathrm{A}-\mathrm{B}-\mathrm{C}$ section from 0 to $2000 \mathrm{~m}$ showed on the map in Fig. 1.

Ross Ice Shelf taking part to the production of Deep Ice Shelf Water (DISW) (Jacobs et al. 1985). This latter is colder $\left(-2.03^{\circ} \mathrm{C}\right)$ and less salty (34.68) than HSSW. The northward branch of HSSW reaches the continental shelf break where it mixes with the Modified Circumpolar Deep Water (MCDW) forming deep and bottom waters (Jacobs et al. 1970, Gordon \& Tchernia 1972, Rodman \& Gordon 1982, Budillon et al. 1999).

Finally the Antarctic Surface Water (AASW) with lower salinity and relatively cold temperatures displays higher variability in its thermohaline fields, reflecting atmospheric influences. This water mass, in fact, shows an extremely 

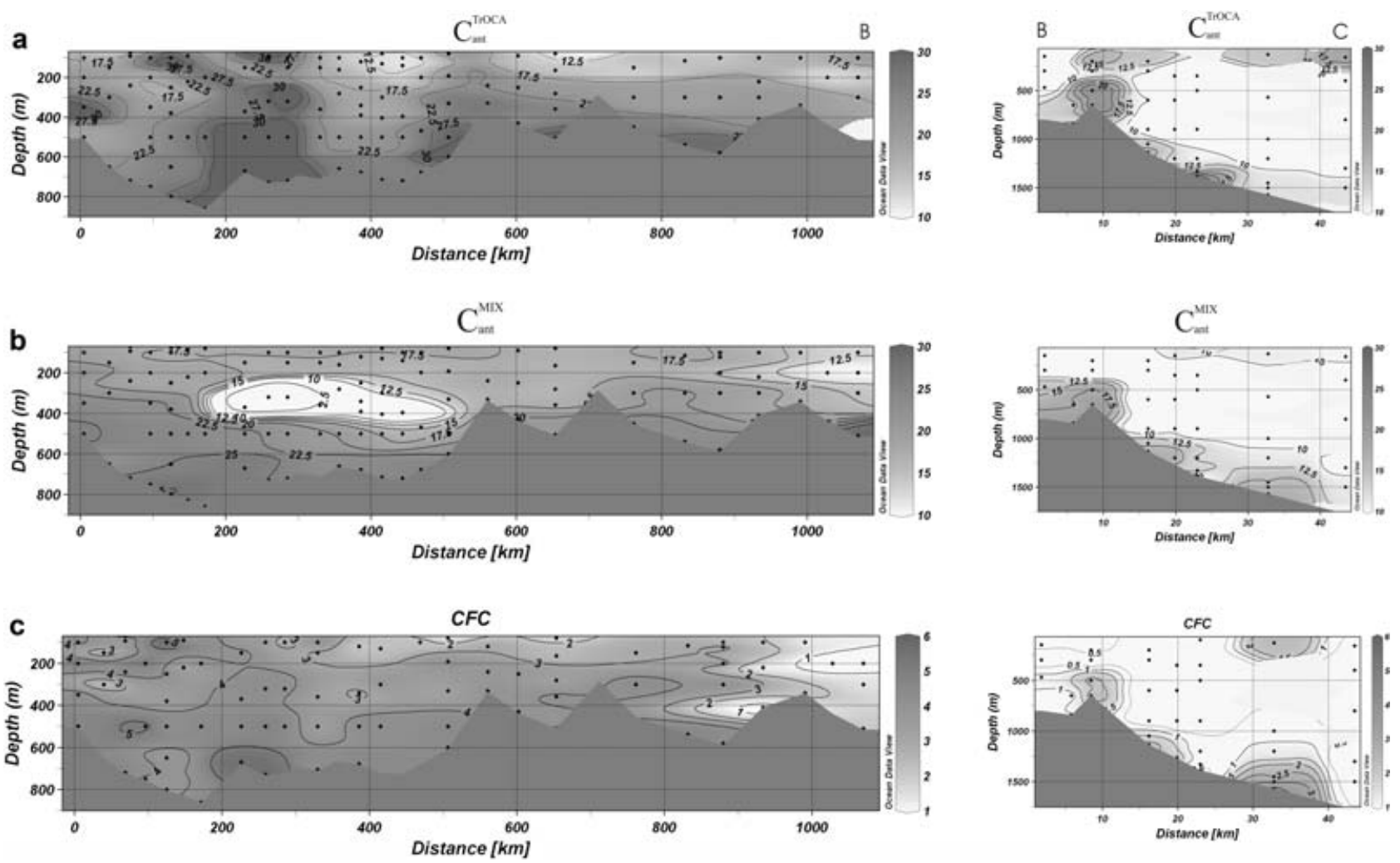

Fig. 4. Anthropogenic $\mathrm{CO}_{2}\left(\mathrm{C}_{\text {ant }}\right)$ distribution in the water column, below the mixed layer depth (70-2000 m), along the A-B-C section showed on the map calculated respectively with a. TrOCA method $\left(\mathbf{C}_{\text {ant }}^{\mathrm{TrOCA}}, \mu \mathrm{mol} \mathrm{kg}{ }^{-1}\right)$, and $\mathbf{b}$. MIX method $\left(\mathbf{C}_{\text {ant }}^{\mathrm{MIX}}, \mu \mathrm{mol} \mathrm{kg}{ }^{-1}\right)$. c. Represent the distribution of CFC-11 ( $\left.\mathrm{pmol} \mathrm{kg}^{-1}\right)$ on the same section between 70 and $2000 \mathrm{~m}$.

variable behaviour, being influenced by ice melting and formation and by atmospheric precipitations (Jacobs et al. 1985). During the 2003 cruise the stations located in the Terra Nova Bay polynya and on the right side of the iceberg B15 displayed typical thermohaline characteristics of AASW as found in literature with temperature ranging between -0.50 and $0^{\circ} \mathrm{C}$ and salinity $>34$, while the remaining stations presented a much colder and less saline surface layer $\left(\mathrm{T}<-1.2^{\circ} \mathrm{C}\right.$ and salinity $\left.<34\right)$ resulting from massive melting of pack ice and/or local wind characteristics.

In this work we show the results obtained for thermohaline fields, carbon properties, dissolved oxygen, anthropogenic carbon and CFC 11 concentrations along a section starting from the tip of the iceberg B15, moving near the Ross Ice Shelf and re-ascending to the area off Cape Adare, in the north-western Ross Sea (Fig. 3).

In general the salinity profile (Fig. 3b) indicates a stratified water column with the highest values at the bottom $(\mathrm{S}>34.70)$. This is indicative of the presence of a HSSW layer in most part of the continental shelf, identified by temperatures close to the surface freezing point $\left(-1.9^{\circ} \mathrm{C}\right)$ also (Fig. 3a). In the B-C sector of the salinity plot we can observe a thin layer of water with salinity $>34.7$ flowing down the slope, evidencing an active down slope process.

\section{$\mathrm{TCO}_{2}, \mathrm{TA}$ and $\mathrm{O}_{2}$ distribution in the studied area}

The different water masses described above and defined by their thermohaline field are also characterized by specific carbonate properties and oxygen concentrations. Table I summarizes the thermohaline properties together with $\mathrm{O}_{2}$, $\mathrm{TA}$ and $\mathrm{TCO}_{2}$ concentrations of the main water sources characterizing the investigated area as measured during the CLIMA cruise (January-March 2003). Next we will describe the distribution of $\mathrm{TA}, \mathrm{TCO}_{2}$ and $\mathrm{O}_{2}$ on the section showed in Fig. 3c-e throughout the Ross Sea.

TA, $\mathrm{TCO}_{2}$ and $\mathrm{O}_{2}$ along this section show a gradient in their vertical distributions. TA and $\mathrm{TCO}_{2}$ increase with depth whereas $\mathrm{O}_{2}$ decreases with depth. $\mathrm{TCO}_{2}$ concentrations range from a minimum of $2148 \mu \mathrm{mol} \mathrm{kg} \mathrm{kg}^{-1}$

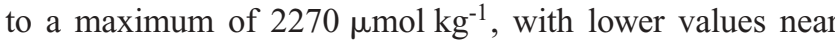
the sea surface reflecting high biological activity and a $\mathrm{CO}_{2}$ removal mainly by photosynthesis. TA concentrations range between 2278 and $2370 \mu \mathrm{mol} \mathrm{kg}^{-1} \mathrm{~g}$. Dissolved oxygen concentrations range from $385 \mu \mathrm{mol} \mathrm{kg}^{-1}$ at the surface to about $190-200 \mu \mathrm{mol} \mathrm{kg}{ }^{-1}$ at intermediate depth, corresponding to the CDW intrusion on the shelf. CDW is well characterized on the $\mathrm{B}-\mathrm{C}$ section (Fig. 3) at stations 92 and 93, in the area across the shelf break off Cape Adare. This water mass is characterized by high 
concentration in TA $\left(2355 \pm 5 \mu \mathrm{mol} \mathrm{kg}^{-1}\right)$ and $\mathrm{TCO}_{2}$ $\left(2261 \pm 4 \mu \mathrm{mol} \mathrm{kg}{ }^{-1}\right)$ and low concentration in $\mathrm{O}_{2}(190 \pm$ $5 \mu \mathrm{mol} \mathrm{\textrm {kg } ^ { - 1 }}$ ). These concentrations are due to the relatively older ventilation age of CDW compared to the recently formed shelf waters, so that the mineralization of organic matter increases its $\mathrm{TCO}_{2}$ concentration consuming $\mathrm{O}_{2}$. CDW intrudes onto the shelf and mixes with shelf waters rising Modified Circumpolar Deep Water (MCDW), characterized by a potential temperature subsurface maximum $\left(-0.84^{\circ} \mathrm{C}\right)$ and a dissolved oxygen minimum $\left(244 \mu \mathrm{mol} \mathrm{kg}{ }^{-1}\right)$. This mixing results in a lower $\mathrm{TCO}_{2}$ content $\left(2250 \mu \mathrm{mol} \mathrm{kg}^{-1}\right)$, which is very close to the typical $\mathrm{TCO}_{2}$ concentration of HSSW filling the bottom of the shelf, therefore these two water masses are not easily distinguishable based on their $\mathrm{TCO}_{2}$ concentrations.

HSSW is present on the bottom at several stations of the continental shelf. For instance, a strong signal is observed in Fig. 3a at casts 33 to 36 at the bottom (salinity > 34.8). Its $\mathrm{TCO}_{2}$ concentration is $2247 \pm 3 \mu \mathrm{mol} \mathrm{kg}^{-1}$, TA is $2355 \pm 2 \mu \mathrm{mol} \mathrm{kg}-1$ and dissolved $\mathrm{O}_{2} 289 \pm 5 \mu \mathrm{mol} \mathrm{kg}{ }^{-1}$.

Finally DISW was observed at casts $38,39,40,48$ as a thin layer at about $300-400 \mathrm{~m}$ depth characterized by a temperature minimum of $-2.1^{\circ} \mathrm{C}$, which is below the surface freezing point. Its $\mathrm{TCO}_{2}$ and TA concentrations (respectively $2242 \pm 4 \mu \mathrm{mol} \mathrm{kg}-1$ and $2339 \pm 3 \mu \mathrm{mol} \mathrm{kg}{ }^{-1}$ ) are lower than those of the HSSW. Since DISW originates from mixing of HSSW with fresh melting water from the base of the Ross Ice Shelf, this water appears colder and less saline than HSSW. The DISW is enriched in dissolved oxygen, reflecting the fact that it contains ventilated HSSW (Rivaro et al. 2003).

The TA, $\mathrm{TCO}_{2}$ and $\mathrm{O}_{2}$ concentrations here reported for the main water masses are in good agreement with the previous study of Sweeney (2003). Nevertheless, the total inorganic carbon presents more variation at the surface water. This could be explained by the fact that during the experiment the area was strongly covered with ice hence surface temperature was colder $\left(-1.2 \pm 0.4^{\circ} \mathrm{C}\right)$ than that reported by Sweeney (2003) $\left(-0.96 \pm 0.25^{\circ} \mathrm{C}\right)$.

\section{Anthropogenic $\mathrm{CO}_{2}$ distribution}

Anthropogenic carbon distribution has been estimated along the same section shown in Fig. 3 using both the MIX method and the recently developed TrOCA method. The results for the two approaches are shown in Fig. 4.

The two methods display similar features. Both of them point out that in the Ross Sea the entire water column has already been invaded by anthropogenic carbon suggesting that the intense ice formation, brine release and vertical convection occurring during the winter in coastal polynyas, as previously observed by Jacobs et al. (1985), represent a pathway for anthropogenic carbon to reach the deepest layers of the oceans. As a result, no water mass in the studied area is sufficiently old to be free of anthropogenic carbon.
Normally the highest concentrations of anthropogenic carbon are found at the surface, because the gas exchange with the atmosphere occurs in the upper oceanic layers. Both the MIX method and the TrOCA method, like the other back calculation methods, cannot be applied in the upper mixed layer (here $0-70 \mathrm{~m}$ ) where numerous biological processes and air-sea $\mathrm{CO}_{2}$ fluxes modify the upper ocean carbon content on a short ( $<$ week) time scale.

From a qualitative point of view the two methods gave similar distribution of anthropogenic carbon: Figure 4 illustrates the different water masses summarized in Table I. They are well distinguishable according to their $\mathrm{C}_{\text {ant }}$ concentrations. The east-west gradient of anthropogenic $\mathrm{CO}_{2}$ revealed by the two methods clearly indicates that the shelf waters are more contaminated than the open sea. The vertical distribution on the shelf (section A-B) shows (for the two methods) an increase of anthropogenic carbon from the mixed layer to depth. In the shelf-to-slope area (section $\mathrm{B}-\mathrm{C}$ ) the two methods found the minimum anthropogenic carbon values in the CDW core and an increase at the bottom layer in correspondence with shelf water downflow.

The CDW intrusion onto the shelf is easily observed by both methods, as well as the outflow of dense shelf water down the slope and the presence of a layer rich in $\mathrm{C}_{\mathrm{ant}}$ on the shelf bottom.

From a quantitative point of view, anthropogenic carbon concentrations estimated using the TrOCA method are slightly higher than those estimated with the MIX model, the average difference being $2 \mu \mathrm{mol} \mathrm{kg}^{-1}$ with a standard deviation of $\pm 7 \mu \mathrm{mol} \mathrm{kg}{ }^{-1}$. This average is within the uncertainties associated with both methods, $\pm 4 \mu \mathrm{mol} \mathrm{kg}{ }^{-1}$ for the TrOCA method and $\pm 7 \mu \mathrm{mol} \mathrm{kg}{ }^{-1}$ for the Mix one.

The minimum concentration of anthropogenic carbon is found in CDW. For this water mass the MIX method estimates a concentration of $5 \pm 1 \mu \mathrm{mol} \mathrm{kg}^{-1}$, and the TrOCA method $9 \pm 3 \mu \mathrm{mol} \mathrm{kg}{ }^{-1}$. The $C_{\text {ant }}$ concentration of

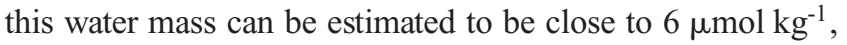
which is in good agreement with previous estimates ranging from 5 to $10 \mu \mathrm{mol} \mathrm{kg}{ }^{-1}$ for this water mass in the Weddell Sea sector (Lo Monaco et al. 2005b).

In Fig. 4 the zoom of plot (b) on the B-C section, across the shelf break off Cape Adare, shows a core of low $\mathrm{C}_{\mathrm{ant}}$ concentration corresponding to the intrusion of CDW onto the shelf. The low concentration of anthropogenic carbon in CDW is not surprizing. In fact it stems from the long residence time of this water mass, segregated at mid-depths for a long time. It is composed of upwelled old deep waters of different origin (Atlantic, Indian and Pacific) in the Southern Ocean (Rintoul et al. 2001). Its relative age, provided by CFC ratios measured in the same area, indicates that its ventilation occurred between 1973 and 1979 (Rivaro et al. 2004a), when atmospheric $\mathrm{CO}_{2}$ was already about $50 \mathrm{ppm}$ higher than its preindustrial concentration $(280 \mathrm{ppm})$. CFCs are transient tracers with 
the characteristic of being entirely anthropogenic, biologically and chemically inert in the ocean. Therefore the oceanic CFC distribution provides valuable information about the rates and pathways of water mass ventilation processes (England \& Maier-Reimer 2001). Moreover, since their global temporal evolution is similar to that of $\mathrm{CO}_{2}$, they are particularly interesting for the study of anthropogenic carbon invasion in the oceans, even though some differences exist in their exchange characteristics at the air-sea interface. The CFC distribution along the section (see Fig. 4c) shows a good agreement with the two anthropogenic $\mathrm{CO}_{2}$ estimates. They all increase from the mixed layer to the bottom on the shelf.

With both methods, the highest concentrations below the mixed layer are associated to HSSW, whose $\mathrm{C}_{\text {ant }}$ content is estimated to be $26 \pm 1 \mu \mathrm{mol} \mathrm{kg}-1$ and $30 \pm 4 \mu \mathrm{mol} \mathrm{kg}{ }^{-1}$, with the MIX and TrOCA method respectively. The highest $\mathrm{C}_{\mathrm{ant}}$ concentration displayed by HSSW agrees with its maximum content in CFC11, up to $2.5 \mathrm{pmol} \mathrm{kg}^{-1}$ (Rivaro et al. 2004a), and its enrichment in dissolved $\mathrm{O}_{2}$, resulting from its recent ventilation. It is in fact the most recently formed water mass in the investigated area. The $\mathrm{CO}_{2}$ excess reported by Chen (1994) in the HSSW around Cape Adare was $25 \pm 10 \mu \mathrm{mol} \mathrm{kg}{ }^{-1}$. The average is of the same order of magnitude as our result, however, the uncertainties associated with the back calculation method used (Chen 1982) are larger than those determined here.

Along the Ross Ice Shelf, on the west part of the section between 100 and $300 \mathrm{~km}$ the TrOCA method revealed high concentrations in $\mathrm{C}_{\text {ant }}$ from $70 \mathrm{~m}$ to the shelf bottom $(700 \mathrm{~m})$. This can also be observed on the CFC section showing high concentrations within the entire water column in that area. The surface seawater, influenced by the Ross Ice Shelf, is colder and less saline than the water around at the same depth (see Fig. 3). The cooling waters are very efficient in the uptake of anthropogenic $\mathrm{CO}_{2}$. The largest difference between the two methods occurs along the Ross Ice Shelf for the DISW, respectively $0.4 \pm 0.3$ and $22 \pm 4 \mu \mathrm{mol} \mathrm{kg}^{-1}$ with the MIX and TrOCA method.

Flowing beneath the Ross Ice Shelf, HSSW starts melting the base of the ice shelf, releasing fresh water. The mixing between HSSW and this melting water produces DISW, whose characteristic $\mathrm{CFC}, \mathrm{O}_{2}, \mathrm{TCO}_{2}$ and TA concentrations are slightly lower than those of the original HSSW, due to fresh water dilution. It's obvious to expect that the same happens for $\mathrm{C}_{\text {ant }}$ concentration, which should be a little bit lower than that of HSSW. Moreover, CFC concentrations in the water column along the Ross Ice Shelf (Fig. 4) indicates that the water around $300 \mathrm{~m}$ is recently formed but is few years older than HSSW, supporting $\mathrm{C}_{\text {ant }}$ concentration estimated by the TrOCA method.

The discrepancies observed on the calculated $\mathrm{C}_{\mathrm{ant}}$ of the DISW suggest that the use of salinity and temperature as conservative tracers together with TA and $\mathrm{O}_{2}$ as non-conservative tracers in the multiparametric analysis is not sufficient to accurately differentiate DISW from the other water masses and hence to accurately estimate the mixing coefficients used in the $\mathrm{C}_{\mathrm{ant}}$ calculation. This means that the signature obtained for DISW with the two couples of conservative and non-conservative tracers used in the MIX method is too close to those of HSSW and AASW. Therefore the DISW is not clearly distinguishable from the other water masses. Consequently the application of the MIX method in this area needs to be improved by adding other conservative tracers, e.g. NO and PO to get a better identification of the water masses.

The absorption of anthropogenic carbon by the young shelf waters at the moment of their formation in the Ross Sea is an important mechanism in $\mathrm{CO}_{2}$ sequestration. In these waters, the absorbed greenhouse gas is allowed to flow out of the shelf and contributes to the formation of Antarctic Bottom Waters (AABW), being in this way sequestered for a long time. The mechanism of formation of AABW involves CDW and the shelf waters: approaching the shelf, CDW mixes with young waters originated in the Ross Sea (HSSW or DISW) to form MCDW and Antarctic Bottom Water (AABW) which contributes to the ventilation of the Southern Ocean (Orsi et al. 2002).

In the $\mathrm{B}-\mathrm{C}$ sector of Figs $3 \& 4$, it is possible to observe that the signal associated to the presence of HSSW at the shelf bottom is still present on the slope as a thin layer characterized by high salinity, low temperature, and high dissolved oxygen. Taking into account the good correlation between hydrographic parameters and dissolved oxygen $\left(r^{2}=0.946\right)$ and applying a two component mixing approach, the HSSW relative fraction at the shelf break and along the slope was calculated (Rivaro et al. 2003). The results yielded a HSSW relative fraction at the shelf break of more than $90 \%$, which decreases to about $50 \%$ at $1500 \mathrm{~m}$, suggesting that an intense ventilation of the deep ocean was occurring during the 2003 CLIMA cruise (Rivaro et al. 2004b).

On the same sector of Fig. 4 the same layer appears also characterized by relatively high concentrations of anthropogenic carbon. This indicates that the shelf waters overflow brings down anthropogenic carbon to the abyssal ocean. CFC measurements during the 2003 CLIMA cruise in the studied area give an approximate age of six years for HSSW found at the bottom of the shelf break, considering the transfer time between the sinking in the formation areas and the outflow at the shelf break. The atmospheric $\mathrm{CO}_{2}$ at the time when this water was in contact with the atmosphere (1997) was about $362 \mu \mathrm{atm}$. The anthropogenic carbon content in this water due to the increase of atmospheric $\mathrm{CO}_{2}$ between preindustrial time and 1997 is estimated to

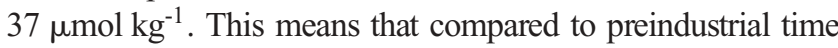
in 1997 there was an excess of $37 \mu \mathrm{mol} \mathrm{kg}{ }^{-1}$ of anthropogenic carbon in seawater. According to this estimate, the HSSW $\left(26 \pm 1 \mu \mathrm{mol} \mathrm{kg}{ }^{-1}\right.$ calculated by the TrOCA method) contributes to the uptake of about $70 \%$ of the anthropogenic carbon when it leaves the surface layer. 
Relationships between the anthropogenic $\mathrm{CO}_{2}$ estimate and $C F C-11$

In this paper CFC-11 concentration is used to assess independently the relevance of the two anthropogenic $\mathrm{CO}_{2}$ estimates. CFCs are interesting anthropogenic tracers to study the anthropogenic $\mathrm{CO}_{2}$ invasion in the ocean since the temporal evolution of their concentrations in the atmosphere is somewhat similar. It must be kept in mind however that significant differences exist between them. The CFC-11 began to increase in the atmosphere in the 1930s in parallel with the outburst of the industrial activity (England \& Maier-Reimer 2001) while anthropogenic $\mathrm{CO}_{2}$ has increased progressively since $\sim 130$ years. Also, the source of emission of CFC differs with those of anthropogenic $\mathrm{CO}_{2}$ and the time of air-sea $\mathrm{CFC}$ equilibration is 10 times shorter (Broecker \& Peng 1982).

The correlations between $\mathrm{CFC}$ and $\mathrm{C}_{\text {ant }}$ estimates are analysed for depth ranging from $70 \mathrm{~m}$ (the maximum mixed layer depth) to $2000 \mathrm{~m}$. The two estimates of anthropogenic $\mathrm{CO}_{2}$ show a good correlation with $\mathrm{CFC}-11$, $r=0.80$ and $r=0.68$ for the Mix and the TrOCA approach respectively. For the Mix method the correlation is tested after removing the data corresponding to the DISW since they are not appropriate. These results are also in excellent agreement with the results obtained in the Indian Ocean using the WOCE data (Touratier et al. 2007).

\section{Inventory of anthropogenic $\mathrm{CO}_{2}$}

The individual estimates of anthropogenic carbon for each station were vertically integrated to determine column inventories. Since $C_{a n t}$ calculations are not reliable in the upper mixed layer, it was assumed that the concentration in the mixed layer was constant and equal to that calculated at the base of this layer. This assumption introduces a potential bias in surface estimates of $\mathrm{C}_{\mathrm{ant}}$ that should not

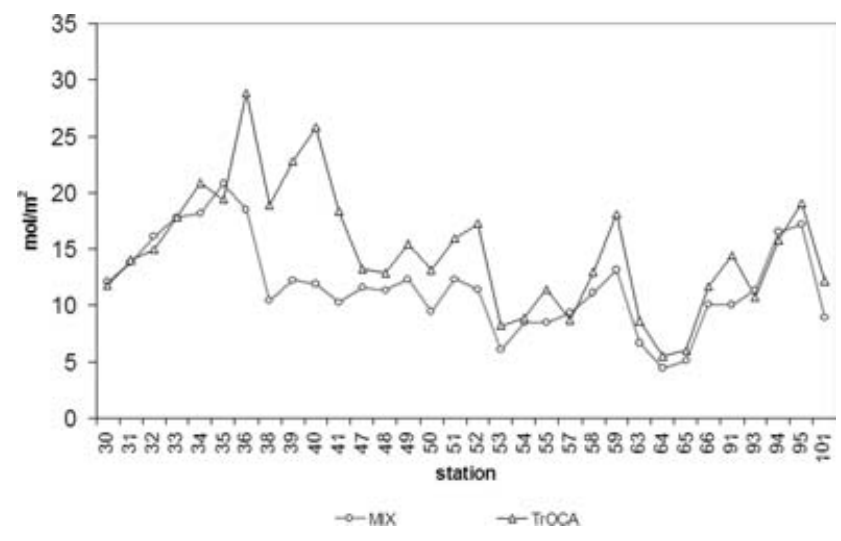

Fig. 5. $\mathrm{C}_{\text {ant }}$ inventory in the Ross Sea along the $\mathrm{A}-\mathrm{B}-\mathrm{C}$ section in mol m$~^{-2}$ estimated with the MIX approach (circles) and with the TrOCA method (triangles). exceed $10 \mu \mathrm{mol} \mathrm{kg}-1$. Integrating this error over $70 \mathrm{~m}$ (the mixed layer thickness) the error on the inventory results less than $1 \mathrm{~mol} \mathrm{~m}^{-2}$.

Figure 5 illustrates the column inventories at each station along the $\mathrm{A}-\mathrm{B}-\mathrm{C}$ section using the MIX and the TrOCA methods. Inventories calculated with the TrOCA method (ranging from 5 to $30 \mathrm{~mol} \mathrm{~m}^{-2}$ with an average of $15 \mathrm{~mol} \mathrm{~m}^{-2}$ ) are very similar or slightly higher than those calculated with the MIX method. The maximum difference $\left(13 \mathrm{~mol} \mathrm{~m}^{-2}\right.$ ) between the two methods corresponds to the stations located along the Ross Ice Shelf where the core of DISW was detected.

As discussed earlier, the two methods provide very different concentrations of anthropogenic carbon for this water mass, and a comparison with CFCs supports the TrOCA estimate. Excluding these stations the maximum difference between the two methods is $5 \mathrm{~mol} \mathrm{~m}^{-2}$. This inventory in the Ross Sea is also in good agreement with results obtained by Lo Monaco et al. (2005b). The deep water formation in the Antarctic polar region contributes actively to the sequestration of the anthropogenic carbon.

\section{Conclusions}

In this study we analysed the inorganic carbon system in the Ross Sea during the late summer 2003. We used two independent methods to estimate the anthropogenic $\mathrm{CO}_{2}$ distribution in the Ross Sea, the recent TrOCA approach and the MIX one. The results of these two methods were also compared with the CFC-11 distribution. The two back calculation methods lead to quite similar results for the distribution of anthropogenic carbon in the studied area. From a quantitative point of view the TrOCA method gave slightly higher concentrations than the MIX one, with an average difference of $2 \pm 7 \mu \mathrm{mol} \mathrm{kg}$. . Nevertheless, these two independent methods provide profiles of similar shape and this is supported by the good correlation with the CFC. Comparing the easiness of the two methods, the TrOCA approch is very easy to use and needs only four parameters (TA, $\mathrm{TCO}_{2}, \theta$ and $\mathrm{O}_{2}$ ) to compute quickly and reliably the anthropogenic carbon distribution.

The main features of the Ross Sea circulation were clearly evidenced through the description of the inorganic carbon properties, dissolved oxygen distribution and $\mathrm{C}_{\mathrm{ant}}$ concentrations. Both methods reveal that in the Ross Sea the entire water column has been invaded by anthropogenic carbon: the maximum concentrations are associated to the recently ventilated HSSW and the minimum to the old CDW.

In the area across the shelf break off Cape Adare, in the north-western part of the Ross Sea, the bottom layer is enriched in anthropogenic carbon, since it contains recently ventilated HSSW. It is very interesting to observe that in this area an active outflow of shelf water is occurring bringing anthropogenic carbon to abyssal depths. Thus, 
bottom waters are supplied with anthropogenic carbon through mixing processes associated with sinking of dense shelf waters.

Our results differ from the first study carried on in this area concerning the sequestration of anthropogenic $\mathrm{CO}_{2}$ (Chen 1994). Chen (1994) concluded, that the $\mathrm{CO}_{2}$ excess in the Cape Adare region does not penetrate deeper than a few hundred metres south of the Polar Front and that the Ross Sea was probably not a significant sink for $\mathrm{CO}_{2}$. Nevertheless, results here presented are in agreement with recent estimates in the Indian Pacific sector of the Antarctic continent (WOCE line SR3) (Sabine et al. 2002) and between South Africa and Antarctica (WOCE line I6) (LoMonaco et al. 2005a). They further confirm that a significant amount of anthropogenic carbon penetrates in and is actually stored into the Southern Ocean. The use of independent methods and independent anthropogenic tracers like CFCs provide efficient tools to compare the available techniques to estimate anthropogenic carbon distribution.

\section{Acknowledgements}

This work was carried out as part of the Italian National Program for Antarctic Research (PNRA) CLIMA project, whose support in the field and laboratory activities is gratefully acknowledged.

Special thanks go to the crew of the RV Italica, who helped to overcome every practical problem. Figures 1-4 were produced utilizing the freeware software Ocean Data View produced by R. Schlitzer from AWI, Bremerhaven (http://www.awi-bremerhaven.de/GEO/ODV), to whom we are grateful. We thank the referees for their constructive and helpful comments.

\section{References}

Aït-Ameur, N. \& GoYet, C. 2006. Distribution and transport of natural and anthropogenic $\mathrm{CO}_{2}$ in the Gulf of Cadiz. Deep-Sea Research II, 53, $1329-1343$.

Bates, N.R., Hansell, D.A. \& Carlson, C.A. 1998. Distribution of $\mathrm{CO}_{2}$ species, estimates of net community production, and air-sea $\mathrm{CO}_{2}$ exchange in the Ross Sea polynya. Journal of Geophysical Research, 103, 2883-2896.

BREWER, P.G. 1978. Direct observation of the oceanic $\mathrm{CO}_{2}$ increase. Geophysical Research Letters, 5, 997-1000.

BROECKER, W.S. 1974. "NO", a conservative water-mass tracer. Earth and Planetary Science Letters, 23, 100-107.

Broecker, W.S. \& Peng, T.H. 1982. Tracers in the sea. Palisades, NY: Eldigio Press, Lamont-Doherty Geological Observatory, $690 \mathrm{pp}$.

Broecker, W.S., Takahashi, T. \& Peng, T.-H. 1985. Reconstruction of past atmospheric $\mathrm{CO}_{2}$ from the chemistry of the contemporary ocean: an evaluation. Washington, DC: Department of Energy, Technical Report TRO 20, 79 pp.

Budillon, G., Fusco, G. \& Spezie, G. 2000. A study of surface heat fluxes in the Ross Sea (Antarctica). Antarctic Science, 12, 243-254.

Budillon, G., Gremes Cordero, S. \& Salusti, E. 2002. On the dense water spreading off the Ross Sea shelf (Southern Ocean). Journal of Marine Systems, 35, 207-227.
Budillon, G., Tucci, S., Artegiani, A. \& Spezie, G. 1999. Water masses and suspended matter characteristics of the western Ross Sea. In Faranda, F.M., Guglielmo, L. \& Ianora, A., eds. Ross Sea ecology. Milan: Springer, 63-93.

Budillon, G., Pacciaroni, M., Cozzi, S., Rivaro, P., Catalano, G., Ianni, C. \& CAntoni, C. 2003. An optimum multiparameter mixing analysis of the shelf waters in the Ross Sea. Antarctic Science, 15, $105-118$.

Bullister, J.L. \& WeIss, R.F. 1988. Determination of $\mathrm{CCl}_{3} \mathrm{~F}$ and $\mathrm{CCl}_{2} \mathrm{~F}_{2}$ in seawater and air. Deep Sea Research, 35, 839-853.

CARMACK, E.C. 1977. Water characteristics of the Southern Ocean south of the Polar Front. In Angel, M. \& Deacon, G., eds. A voyage of discovery. 70th Anniversary volume. Supplement to Deep-Sea Research. Elmsford, NY: Pergamon Press, 15-42.

Chen, C.-T.A. 1982. On the distribution of anthropogenic $\mathrm{CO}_{2}$ in the Atlantic and Southern oceans. Deep-Sea Research, 29, 563-580.

Chen, C.-T.A. 1994. Some indications of excess $\mathrm{CO}_{2}$ penetration near Cape Adare off the Ross Sea. La Mer, 32, 167-172.

Chen, C.T. \& Drake, E.T. 1986. Carbon dioxide increase in the atmosphere and oceans and possible effects on climate. Annual Review of Earth and Planetary Sciences, 14, 201-235.

Chen, C.-T.A. \& Millero, F.J. 1979. Gradual increase of oceanic $\mathrm{CO}_{2}$. Nature, 277, 205-206.

Coatanoan, C., Goyet, C., Gruber, N., Sabine, C.L. \& Warner, M. 2001. Comparison of two approaches to quantify anthropogenic $\mathrm{CO}_{2}$ in the ocean: results from the northern Indian Ocean. Global Biogeochemical Cycles, 15, 11-25.

Dickson, A.G. 1981. An exact definition of total alkalinity, and a procedure for the estimation of alkalinity and total inorganic carbon from titration data. Deep-Sea Research, 28, 609-623.

Dickson, A.G. \& GoYET, C., eds. 1994. Handbook of methods for analysis of the various parameters of the carbon dioxide system in sea water. version 2. London: DOE. ORNL/CDIAC-74.

Dinniman, M.S., KLINCK, J.M. \& SMith JR, W.O. 2003. Cross-shelf exchange in a model of the Ross Sea circulation and biogeochemistry. Deep-Sea Research II, 50, 3103-3120.

DoneY, S.C. \& Hecht, M.W. 2001. Antarctic Bottom Water formation and deep water chlorofluorocarbon distributions in a global ocean climate model. Journal of Physical Oceanography, 32, $1642-1666$.

EDMOND, J.M. 1970. High precision determination of titration alkalinity and total carbon dioxide content of seawater by potentiometric titration. DeepSea Research, 17, 737-750.

England, M.H. \& Maier-Reimer, E. 2001. Using chemical tracers to assess ocean models. Reviews of Geophysics, 39, 29-70.

FRIIS, K. 2006. A review of marine anthropogenic $\mathrm{CO}_{2}$ definitions: introducing a thermodynamic approach based on observations. Tellus, B58, 2-15.

Gordon, A.L. \& TCHERniA, P. 1972. Waters of the continental margin off Adélie coast, Antarctica. Antarctic Research Series, 19, 56-69.

Gordon, L.I., Codispoti, L.A., Jennings JR, J.C., Millero, F.J., Morrison, J.M. \& SweEney, C. 2000. Seasonal evolution of hydrographic properties in the Ross Sea, Antarctica, 1996-1997. Deep-Sea Research II, 47, 3095-3117.

Gouretsky, V. 1999. The large-scale thermohaline structure of the Ross Gyre. In Spezie, G. \& Manzella, G.M.R., eds. Oceanography of the Ross Sea, Antarctica. Berlin: Springer, 77-100.

Goyet, C., Coatanoan, C., Eischeid, G., Amaoka, T., Okuda, K., Healy, R. \& TsuNOGAI, S. 1999. Spatial variation of total alkalinity in the northern Indian Ocean: a novel approach for the quantification of anthropogenic $\mathrm{CO}_{2}$ in seawater. Journal of Marine Research, 57, 135-163.

GrasshofF, K. 1983. Determination of oxygen. In GrasshofF, K., EHRHARDT, M. \& Kremlig, K., eds. Methods of sea water analysis. Weinheim: Verlag Chemie, 61-72.

Gruber, N. 1998. Anthropogenic $\mathrm{CO}_{2}$ in the Atlantic Ocean. Global Biogeochemical Cycles, 12, 165-191. 
Hoppema, M., Fahrbach, E., Stoll, M.H.C. \& De BaAr, H.J.W. 1998. Increase of carbon dioxide in the bottom water of the Weddell Sea, Antarctica. Marine Chemistry, 59, 201-210.

Hoppema, M., Roether, W., Bellerby, R.G.J. \& De BaAr, H.J.W. 2001. Direct measurements reveal insignificant storage of anthropogenic $\mathrm{CO}_{2}$ in the abyssal Weddell Sea. Geophysical Research Letters, 28, $1747-1750$.

Hoppema, M., De BaAr, H.J.W., Fahrbach, E. \& Bellerby, R.G.J. 2002. Renewal time and transport of unventilated Central Intermediate Water of the Weddell Sea derived from biogeochemical properties. Journal of Marine Research, 60, 677-697.

IPCC. 2001. Climate change 2001: the scientific basis. Contribution of Working Group I to the third assessment report of the Intergovernmental Panel on Climate Change. Cambridge: Cambridge University Press, $881 \mathrm{pp}$.

JACoBs, S.S. \& Comiso, J.C. 1989. Sea ice and oceanic processes on the Ross Sea continental shelf. Journal of Geophysical Research, 94, $18195-18211$

JACOBS, S.S. \& Giulivi, C.F. 1998. Interannual ocean and sea ice variability in the Ross Sea. Antarctic Research Series, 75, 135-150.

JACOBS, S.S. \& Giulivi, C.F. 1999. Thermohaline data and ocean circulation on the Ross Sea continental shelf. In Spezie, G. \& Manzella, G.M.R., eds Oceanography of the Ross Sea, Antarctica. Berlin: Springer, 3-16.

Jacobs, S.S., Amos, A.F. \& Bruchhausen, P.M. 1970. Ross Sea oceanography and Antarctic Bottom Water formation. Deep-Sea Research, 17, 935-962.

Jacobs, S.S., Fairbanks, R.G. \& Horibe, Y. 1985. Origin and evolution of water masses near the Antarctic continental margin: evidence from $\mathrm{H}_{2}^{18} \mathrm{O}=\mathrm{H}_{2}^{16} \mathrm{O}$ ratios in seawater. Antarctic Research Series, 43, 59-85.

Kurtz, D.D. \& Bromwich, D.H. 1983. Satellite observed behavior of the Terra Nova Bay polynya. Journal of Geophysical Research, 88, 9717-9722.

Kurtz, D.D. \& Bromwich, D.H. 1985. A recurring atmospherically-forced polynya in Terra Nova Bay. Antarctic Research Series, 43, 177-201.

LocARnINI, R.A. 1994. Water masses and circulation in the Ross Sea Gyre environs. $\mathrm{PhD}$ thesis, Texas A \& M University, College Station, 87 pp. [Unpublished].

Lo Monaco, C., Metzl, N., Poisson, A., Brunet, C. \& Schauer, B. 2005a. Anthropogenic $\mathrm{CO}_{2}$ in the Southern Ocean: distribution and inventory at the Indian-Atlantic boundary (World Ocean Circulation Experiment line I6). Journal of Geophysical Research, 110, doi:10.1029/2004JC002643.

Lo Monaco, C., Goyet, C., Metzl, N., Poisson, A. \& Touratier, F. 2005 b. Distribution and inventory of anthropogenic $\mathrm{CO}_{2}$ in the Southern Ocean: comparison of three data-based methods. Journal of Geophysical Research, 110, doi:10.1029/2004JC002571.

Mackas, D.L., Denman, K.L. \& Bennett, A.F. 1987. Least squares multiple tracer analysis of water mass composition. Journal of Geophysical Research, 92, 2907-2918.

Matear, R.J. \& Hirst, A.C. 1999. Climate change feedback on the future oceanic $\mathrm{CO}_{2}$ uptake. Tellus, B51, 722-733.

Meredith, M.P., Watson, A.J., Van Scoy, K.A. \& Haine, T.W.N. 2001. Chlorofluorocarbon-derived formation rates of the deep and bottom waters of the Weddell Sea. Journal of Geophysical Research, 106, 2899-2919.

Orsi, A.H., Johnson, G.C. \& Bullister, J.L. 1999. Circulation, mixing and production of Antarctic bottom water. Progress in Oceanography, 43, $55-109$.

Orsi, A.H., Smethie, W.M. \& Bullister, J.L. 2002. On the total input of Antarctic waters to the deep ocean: a preliminary estimate from chlorofluorocarbon measurements. Journal of Geophysical Research, 107, 31.1-31.14.

Park, Y.-H., Charriaud, E., Ruiz Pino, D. \& Jeandel, C. 1998. Seasonal and interannual variability of the mixed layer properties and steric height at station KERFIX, southwest of Kerguelen. Journal of Marine Systems, $17,571-586$.
Pérez, F.F., Álvarez, M. \& Ríos, A.F. 2002. Improvements on the backcalculation technique for estimating anthropogenic $\mathrm{CO}_{2}$. Deep Sea Research, 49, 859-875.

Poisson, A. \& CHEN, C.T.A. 1987. Why is there little anthropogenic $\mathrm{CO}_{2}$ in Antarctic Bottom Water. Deep Sea Research, 34, 1255-1275.

Price, J. \& Baringer, M. 1994. Outflows and deep water production by marginal seas. Progresses in Oceanography, 33, 161-200.

Price, J.F., Mooers, C.N.K. \& Van Leer, J.C. 1978. Observation and simulation of storm-induced mixed-layer deepening. Journal of Physical Oceanography, 8, 582-599.

Rintoul, S.R., Hughes, C.W. \& Olbers, D. 2001. The Antarctic Circumpolar Current system. In Siedler, G., Church, J. \& Gould, J., eds. Ocean circulation and climate. San Diego, CA: Academic Press, $271-302$.

Rivaro, P., Frache, R., Bergamasco, A. \& Hohmann, R. 2003. Dissolved Oxygen, NO and PO as tracers for Ross Sea Ice Shelf Water overflow. Antarctic Science, 15, 399-404.

Rivaro, P., Budillon, G., Massolo, S., Bergamasco, A. \& Spezie, G. 2004b. Chlorofluorocarbon signature of the shelf waters in the western Ross Sea. SCAR Open Conference Abstracts, Bremen, Germany, 25-31.07.

Rivaro, P., Bergamasco, A., Budillon, G., Frache, R., Hohmann, R., Massolo, S. \& Spezie, G. 2004a. Chlorofluorocarbon distribution in the Ross Sea water masses. Chemistry and Ecology, 20, S29-S41.

Rodman, M. \& Gordon, A. 1982. Southern Ocean bottom waters in the Australia-New Zealand sector. Journal of Geophysical Research, 87, $5771-5778$.

Sabine, C.L. \& Feely, R.A. 2001. Comparison of recent Indian Ocean anthropogenic $\mathrm{CO}_{2}$ estimates with a historical approach. Global Biogeochemical Cycles, 15, 31-42.

Sabine, C.L., Key, R.M., Johnson, K.M., Millero, F.J., Poisson, A., Sarmiento, J.L., Wallace, D.W.R \& WinN, C.D. 1999. Anthropogenic $\mathrm{CO}_{2}$ inventory of the Indian Ocean. Global Biogeochemical Cycles, 13, 179-198.

Sabine, C.L., Feely, R.A., Key, R.M., Bullister, J.L., Millero, F.J., Lee, K., Peng, T.H., Tilbrook, B., Ono, T. \& Wong, C.S. 2002. Distribution of anthropogenic $\mathrm{CO}_{2}$ in the Pacific Ocean. Global Biogeochemical Cycles, 16, art. 1083.

Sabine, C.L., Feely, R.A., Gruber, N., Key, R.M., Lee, K., Bullister, J.L., Wanninkhof, R., Wong, C.S., Wallace, D.W.R., Tilbrook, B., Millero, F.J., Peng, T.-H., Kozyr, A. \& Ono, T., Rios, A. F. 2004. The oceanic sink for anthropogenic $\mathrm{CO}_{2}$. Science, 305, 367-371.

Sarmiento, J. L., Gruber, N. 2002. Sinks for anthropogenic carbon. Physics Today, 55, 30-36.

Sarmiento, J.L., Hughes, T.M.C. \& Stouffer, R.J. 1998. Simulated response of the ocean carbon cycle to anthropogenic climate warming. Nature, 393, 245-249.

SHILler, A.M. 1981. Calculating the oceanic $\mathrm{CO}_{2}$ increase: a need for caution. Journal of Geophysical Research, 86, $11083-11088$.

Smethie, W.M., Chipman, D., Swift, J. \& Koltermann, K. 1988. Chlorofluoromethanes in the Arctic Mediterranean seas: evidence for formation of bottom water in the Eurasian Basin and deep-water exchange through Fram Strait. Deep Sea Research, 35, 347-369.

SweEnEy, C. 2003. The annual cycle of surface $\mathrm{CO}_{2}$ and $\mathrm{O}_{2}$ in the Ross Sea: a model for gas exchange on the continental shelves of Antarctica. Antarctic Research Series, 78, 295-312.

Sweeney, C., Hansell, D.A., Carlson, C.A., Codispoti, L.A., Gordon, L.I., Marra, J., Millero, F.J., Smith, W.O. \& Takahashi, T. 2000a. Biogeochemical regimes, net community production and carbon export in the Ross Sea, Antarctica. Deep-Sea Research II, 47, 3369-3394.

Sweeney, C., Smith, W.O., Hales, B., Bidigare, R.R., Carlson, C.A., Codispoti, L.A., Gordon, L.I., Hansell, D.A., Millero, F.J., PARK, M.-O. \& TAKAhAshi, T. 2000b. Nutrient and carbon removal ratios and fluxes in the Ross Sea, Antarctica. Deep-Sea Research II, 47, $3395-3421$ 
TomczaK, M. 1981. A multiparameter extension of temperature/salinity diagram techniques for the analysis of non-isopycnal mixing. Progresses in Oceanography, 10, 147-171.

TOMCZAK, M. \& LARGE, D.G.B. 1989. Optimum multiparameter analysis of mixing in the thermocline of the Eastern Indian Ocean. Journal of Geophysical Research, 94, 16 141-16 149.

Touratier, F. \& Goyet, C. 2004a. Definition, properties, and Atlantic Ocean distribution of the new tracer 'TrOCA'. Journal of Marine Systems, 46, $181-197$.

Touratier, F. \& Goyet, C. 2004b. Applying the new TrOCA approach to assess the distribution of anthropogenic $\mathrm{CO}_{2}$ in the Atlantic Ocean. Journal of Marine Systems, 46, 181-197.
Touratier, F., Azouzi, L. \& Goyet, C. 2007. CFC-11, $\Delta^{14} \mathrm{C}$ and ${ }^{3} \mathrm{H}$ tracers as a means to assess anthropogenic $\mathrm{CO}_{2}$ concentrations in the ocean. Tellus, 59B, 318-375.

Touratier, F., Goyet, C., Coatanoan, C. \& Andrié, C. 2005. Assessments of anthropogenic $\mathrm{CO}_{2}$ distribution in the tropical Atlantic Ocean. Deep Sea Research I, 52, 2275-2284.

VAN Woert, M.L. 1999. Wintertime dynamics of the Terra Nova Bay polynya. Journal of Geophysical Research, 104, 77537769.

You, Y. \& TomczaK, M. 1993. Thermocline circulation and ventilation in the Indian Ocean derived from water mass analysis. Deep-Sea Research, 40, $13-56$. 